\title{
The Roles of Police Officers in Fiduciary Execution
}

\author{
Mochammad Dja' is ${ }^{1}$, Malikhatun Badriyah ${ }^{2}$ \\ \{mochammaddjais73@gmail.com ${ }^{1}$, malikha_b@yahoo.com $\left.{ }^{2}\right\}$ \\ ${ }^{1,2}$ Diponegoro University, Semarang, Indonesia
}

\begin{abstract}
Regulation of Chief of the Indonesian National Police regarding Fiduciary Execution is the legal foundation for Police Officers to participate in Fiduciary Execution to make the execution works safely, orderly, smoothly, responsible, and protective to related parties. This research aims to unveil the types of fiduciary execution which needs police security, the suitability of police officers' role based on the Regulation of the Chief of the Indonesian National Police with Civil Execution Law, and the causes of absence for the help of security requested to Police Officers in Central Java. Law materials and data were obtained from the literature study and fields survey (interview and document review) at Regional Police of Central Java and City Police of Semarang. Based on the qualitative analysis, execution of judge's help, separate executive, and sales execution in the market needed police security assistance, while underhand sales execution and stock exchange trading execution do not need the help of police security. The setting of Police Officers role in the Regulation of Chief of the Indonesian National Police regarding Fiduciary Execution was not by the Civil Law Execution. The causes of the absence of security request to Police Officers in Central Java were the type of fiduciary execution used. Creditors do not need police security, and there are burdening requirements for the creditor. It is suggested for the Chief of the Indonesian National Police to improve the Regulation of Chief of the Indonesian National Police regarding Fiduciary Execution.
\end{abstract}

Keyword:execution, fiduciary, roles of police

\section{Introduction}

In the Act Number 42 the year 1999 regarding Fiduciary Guarantee (called as Act of Fiduciary), it is stated that a Certificate of Fiduciary Guarantee which enlists the words "FOR THE SAKE OF JUSTICE UNDER THE GOD THE ALMIGHTY" has executorial power. If the debtor breaches the contract, the receiver of fiduciary has the rights to sell the object of fiduciary guarantee by himself, without going through litigation path. Tables are not prescribed, although the various table text styles are provided. The formatter will need to create these components, incorporating the applicable criteria that follow.

The fiduciary guarantee has been used in Indonesia since the era of Dutch colonization as the form of guarantee from a court decision. The fiduciary guarantee is widely used in the transaction of loan due to its simple, easy, and quick access. Somehow, it lacks legal assurance and does not have executorial power.

Concerning about the execution of fiduciary object (called as fiduciary execution), this execution is out of conventional "execution defined as the conduct of verdict"[1] [2] [3]][4] [5]. In this article, the execution is defined as "a forced attempt to realize rights and sanctions" [6].

In 22nd of June 2011, the Chief of the Indonesian National Police released Regulation Number 8 the Year 2011 regarding the Security for Fiduciary Execution, as stated in the State 
Gazette Year 2011 Number 360, which is then called as the Regulation of Chief of the Indonesian National Police regarding Fiduciary Execution. This provision becomes the basis of the Indonesian National Police to participate in the execution of the fiduciary object.

Based on the pre-survey, since the release of the Regulation of Chief of the Indonesian National Police regarding Fiduciary Execution to June 2017 (six years), there is no request to the security of fiduciary guarantee's execution in the Regional Police of Central Java, especially in the City Police of Semarang. From the problems above, some questions are raised as follows.

1. What are the roles of Police Officers based on the Regulation of Chief of the Indonesian National Police regarding Fiduciary Execution by Civil Law Execution?

2. What are the types of fiduciary execution which need security assistance from the Police Officers?

3. Why is there an absence of fiduciary security request in the Regional Police of Central Java and City Police of Semarang?

\section{Methodology}

Before the survey on the fields was done, there was a pre-survey to know the existence of security request to fiduciary execution to the Regional Police of Central Java, mainly to the City Police of Semarang.

This research is original because there was no previous research regarding the roles of the Indonesian National Police in the fiduciary execution. The primary, secondary, and tertiary legal materials were obtained from library research with the collector of document review. The data about the role of police officers in the fiduciary execution were obtained through field survey (interview) to the Regional Police of Central Java, City Police of Semarang, and financial institution. Qualitative analysis is used for the research especially for the Regulation of Chief of the Indonesian National Police regarding Fiduciary Execution to measure the factors causing the Regional Police of Central Java, mainly City Police of Semarang, not to participate in the fiduciary execution.

\section{Findings}

3.1 The role of police officers in the execution of fiduciary based on the Regulation of Chief of the Indonesian National Police regarding Fiduciary Execution and Civil Law Execution

In the weighing section of the Regulation of Chief of the Indonesian National Police regarding Fiduciary Execution, it is stated that "the execution of fiduciary guarantee has legal power which has the same binds to verdicts with permanent legal forces." This statement is not valid. Based on Article 15 of Act of Fiduciary, the one which has legal power which has the same binds to verdicts with permanent legal forces is a fiduciary certificate which enlists the words "FOR THE SAKE OF JUSTICE UNDER THE GOD THE ALMIGHTY," instead of the fiduciary execution. Meanwhile, the fiduciary execution was done with the same procedure of court verdicts which has reached exact legal forces (in Kracht van gewijsde). In Civil Law Execution, the procedure of execution in the act of Fiduciary Article 29 includes ordinary execution or execution with paying the amount of money.

The aim of fiduciary execution by police officers is to hold secure, orderly, smoothly, and responsible fiduciary execution; and provide protection and security to the receiver of 
Fiduciary Guarantee and the society (Article 2 of the Regulation of Chief of the Indonesian National Police regarding Fiduciary Execution).

"Fiduciary execution as regulated in the act of Fiduciary is one of the execution nonreceivable of the nation[6] included as the group of Civil Law Execution." Thus, the provision of public execution (especially execution of judge's verdict) about the role of police officers is valid in fiduciary execution.

The nature of the judge's verdict execution is merely to enforce the nation's wisdom. About that, the execution includes the principle of "in any condition, execution should be done." This principle is realized on the concrete legal provision of emptying of permanent object Article 200 (11) HIR (Herziene Indonesisch Reglement), the Act of the Indonesian Procedure Law, which states "deesnoods met behulp van den starken arm."

The terms "de sterke arm" is then translated as the "Nation's power apparatus"[7] or "manus militaris; police officers or military in doing certain action: in civil matters, emptying, etc.: confiscation with police helps"[8] ; and "under police helps"[9].

Based on the translation, the terms "deesnoods met behulp van den starken arm" means "if it is needed, by the nation's power apparatuses." The apparatuses provide helps in running the execution well; not only securing and saving the executor officers in the execution. The apparatuses have to take action to face the protests against the execution based on the ethical procedures, and if it is needed, they can arrest the offender as stated in Article 212 of the Book of Criminal Law.

This is in accordance with the opinion of Claire Sandbrook who said that: "I believe that detailed planning has given the police an appreciation of court orders made to recover possession of land, and as a result of the way in High Court Enforcement Officers (HCEOs) in particular, have risen to the challenge of working to policing standards. It is vital that there is a working relationship between HCEOs and the police to ensure that these difficult operations are carried out smoothly, with SAFETY being of paramount concern to everyone affected by the enforcement of the court's order." [10].

Based on the above explanation, the role of police officers in the fiduciary execution according to the Regulation of Chief of the Indonesian National Police regarding Fiduciary Execution is different from the provision in Civil Law Execution.

\subsection{Types of fiduciary execution which need security assistance from Police Officers Units}

Fiduciary execution is done in two steps. The first step is the initial execution. The second step is the main execution.

In case if the debtor is the default, the object of fiduciary guarantee has to be given to the creditor who receives the fiduciary. The disapproval of debtors' repayment raises the rights of the creditor as the receiver of fiduciary to force the action of initial execution (Article 30 Act of Fiduciary and its explanation).

Initial execution aims to control the object of fiduciary guarantee by creditor/receiver of fiduciary. Without this control, the execution will be difficult or even unable to happen. The creditor or his attorney do initial execution. In doing this step, the creditor has to show the original certificate of fiduciary (not the copy version), and the attorney should show the certificate along with the letter of power of attorney from the creditor. Without these requirements, the debtor can reject the action of initial execution. 
The types of fiduciary execution are the execution of the help of the judges, separate executive, and execution of underhand sales, market sales execution, and stock exchange trading (Article 29 and Article 31 Act of Fiduciary)

\subsubsection{The procedure of judges' help execution.}

The execution of judges' help in fiduciary cases is done to the certificate of fiduciary which enlists the words "FOR THE SAKE OF JUSTICE UNDER THE GOD THE ALMIGHTY." The procedure of this execution is the same as the execution of a court verdict in Kracht van gewijsde (Article 195-Article 206 HIR).

In the initial execution, there are two possibilities upon judges' help. First, it is started with an initial execution that the object of fiduciary becomes the object fiduciary execution controlled by the pleader of execution. The execution of judges' help begins with the request of execution to the Chairman of District Court, banning (warning), executorial confiscation, and auction sales through KPKNL (Kantor Pelayanan Kekayaan Negara dan Lelang or State Assets and Auction Service Office).

Second, the execution of judges' help can be done without initial execution. In this case, the object of fiduciary which will be executed is still controlled by the debtor or the giver of fiduciary. The procedure is the same as the first one with the difference in the step of executorial confiscation as well as the force to take a fiduciary object from the giver or controller of fiduciary.

The security helps from the police officers is needed in the initial execution or force-taking of the fiduciary object to be auctioned.

\subsubsection{The procedure of separate executive.}

Pirate executive is done to a fiduciary certificate which enlists the words "FOR THE SAKE OF JUSTICE UNDER THE GOD THE ALMIGHTY" and agreement of selling object under the power of creditor as the receiver of fiduciary. The procedure of separate executive directly comes from the auction of fiduciary guarantee object to the KPKNL, with protected area copes the place of the auctioned object.

Before the sale of the auction of fiduciary guarantee objects through KPKNL, the initial execution is held. The help of police security is needed in this initial execution.

\subsubsection{The procedure of execution of underhand sales.}

If the debtor is the default, the execution to the object of a fiduciary can be done by underhand sales based on the deal between the giver and receiver of fiduciary to obtain the highest price to share benefit to both parties [Article 29 (1) c jo. Article 29 (2) Act of Fiduciary].

As the requirement of "the agreement of the giver and receiver of fiduciary," it can execute the underhand or assigned sales. The deal will avoid the conflict. Thus, the help from the police officers is not needed. 


\subsubsection{Procedures of execution in-market sales.}

If the object of a fiduciary is traded object and the debtor is a default, the execution of sales to fiduciary guarantee can be sold in the market, (Article 31 Act of Fiduciary). The help from the police officers is needed in the initial or foremost execution.

\subsubsection{Procedures of sales in stock exchange trading.}

The legal foundation of the fiduciary object is the same as the foundation of market sales in the Article 31 Act of Fiduciary. Things which become the object of fiduciary guarantee consist of the stock which can be sold in the exchange, making the execution of sales can be done in a particular area. From the Law of Goods and securities, the stock is not a material, but evidence. In this case, the material is the account receivable proven by the securities. During the agreement of fiduciary agreement, the stock becomes the object of fiduciary under the control of the fiduciary receiver. Therefore, the execution does not need initial execution in this case, which means the help from police officers are not needed.

\subsection{The cause of the absence of security request to fiduciary execution in Regional Police of Central Java and City Police of Semarang}

\subsection{Causes of the absence of security request to fiduciary execution from Act of Fiduciary.}

According to the Act of Fiduciary, there are some execution types which do not need security helps. It is because the creditor initially controls the object of the execution as the receiver of fiduciary. The type of execution is the sales in the stock exchange trading (Article 31 Act of Fiduciary). Besides, the execution can be done between the debtor as the giver of fiduciary with the creditor as the receiver. The types of this execution are the underhand/assigned sales [Article 29 (1) c jo. Article 29 (2) Act of Fiduciary].

\subsection{Causes of the absence of security request to fiduciary execution from The Regulation of Chief of the Indonesian National Police regarding Fiduciary Execution.}

To obtain security in the execution of fiduciary guarantee, there should be a written request made by the receiver of fiduciary or attorney to the Head of Regional Police or Residential Police where the execution happens. Besides the receiver of fiduciary or its attorney, the request of security can be made by a third party (executor officer) who acts based on the cooperative agreement between fiduciary actors. (Article 7, jo. Article 9 The Regulation of Chief of the Indonesian National Police regarding Fiduciary Execution).

In Article 8 of the Regulation of Chief of the Indonesian National Police regarding Fiduciary Execution, the request of execution security should be proposed with the attachment of:

- Copy of fiduciary guarantee acts;

- Copy of Certificate of Fiduciary Guarantee;

- Warning letter to the debtor to repay which has been given more than twice, proven with a receipt;

- Identity of executor officers; and 
- Official letter of assignment for the execution.

After the creditor as the receiver of fiduciary, the requirement of warning letter to the debtor to fulfill their responsibility to repay twice, proven with receipt is burdening; since, in fiduciary agreement, it is determined that the overdue of the repayment in certain times from the debtor automatically made the debtor default.

The opinion of the creditor is accurate as it is based on the Article 1238 of Civil Codes.

\subsubsection{Creditor, as the fiduciary receiver, does not need the help of police officers.}

The creditor/receiver of a fiduciary is the one who runs the business of finance, making their action always be based on business consideration. From this consideration, there are two critical things on the procedure of security by police officers and the value of the execution object.

The security helps of the Regulation of Chief of the Indonesian National Police regarding Fiduciary Execution should be based on a specific procedure which involves much personnel. According to the Regulation of Chief of the Indonesian National Police regarding Fiduciary Execution, the request of security can be given to the Head of Regional or City Police.

The procedure of security helps in fiduciary execution includes the following actions.

1) Research completeness and validity of security request requirements for fiduciary execution to determine acceptance or rejection of security request.

2) Preparation and Planning of Security to fiduciary execution. If from the research is known that the applicant has fulfilled the requirement, the Head of Regional Police or the Head of City Police will order the Head of Operational Bureau from them Regional Police or City Police to prepare, plan, and do the security services to the execution.

3) The execution. It consists of three steps: preparation, execution, and monitoring and control.

Preparation includes the arrangement of planning and coordination meeting. It includes intelligence prediction and execution security which involves the time of execution, budgeting, devices, security patterns, and action. The meeting of coordination includes the explanation of legal status to fiduciary guarantee, the condition and nature of threats in the location of execution, the number of personals needed by Indonesian National Police, the devices, and the action.

Execution includes preparation and execution.

The preparation includes

a) Checking the real number of personals and devices of security;

b) Giving the direction to personals which will execute the security action;

c) Explaining the action in security action;

d) Dividing the tasks of personals; and

e) Shifts of personals.

The execution of security to fiduciary execution done by:

a) Appeal to not involved parties to leave the execution location;

b) Doing strict security action during the dialogue and negotiation between the executor officers and the executed parties;

c) Protecting the executor officers and applicant, executed society in the location;

d) Observing, monitoring, and signing people who are trying to block the execution; and 
e) Securing and monitoring the things and materials which will be executed.

The execution should work securely, orderly, and smoothly with passive security personals. In contrast, if in the execution, there is a fight from the executed, the personals will be active in:

a) Securing and catching people who initiate the fights or conducting action against the law;

b) Searching people who bring fire gun, sharp weapon, and other dangerous tools;

c) Confiscate the fire gun, sharp weapon, and other dangerous tools from the location; and

d) Localized and insulate the way from and to the location of execution.

In terms of the increasing security escalation which endangers the members, the controller of the fields can immediately report and ask the help from the mass controller or Mobile Brigade Corps to:

a) Head of City Police, if the City Police do it; and

b) Head of Regional Police if Regional Police do it.

The Head of the Police can directly send the help of personals to the location.

In case if the executed has repaid to other officer chosen by the executor, causing disputes in the execution, states that the personals of Indonesian National Police who do the security action can do the following actions:

a) Initiating persuasive approach to the applicant and pleated to conduct discussion;

b) Asking politely to the pleated to show the supporting documents or evidence of the repayment;

c) Securing the environment around for the execution to avoid the escalation of security; and

d) If the pleated has the proofs or evidence, the personnel of the Indonesian National Police:

(1) Delay or stop the execution;

(2) Brings and give the officers who are appointed by the applicant to the investigator of the Indonesian National Police for further action; and

(3) Brings the pleated and applicant of the execution to the nearby police officers for further action.

Monitoring and Control were done in preparation and execution. In the preparation, control and monitoring are done in the arrangement of security planning, preparing personals and devices, executing the security, and consolidation. Monitoring and control of security in the steps of execution are done directly or indirectly. Direct monitoring and control occur under the order of managers. In the indirect path, the monitoring and control are done by monitoring all sequences of actions in the execution through communication or reports. These security actions in the execution are merely led by the leader step by step based on their job description and responsibility on the structure of the security organization. The steps in the execution of fiduciary execution aim to ensure that the planning has been adjusted to the situation, condition, and threats which will be faced as well as ensuring that the needed personnel and devices have been ready and adjusted to the needs of security, preventing and avoiding the actor who conducts deviant behavior out of the procedure and/or exceeding the limit of their authority, and ensuring that the security action has been done based on the responsible procedure. 
Based on the explanation of the preparation, execution, and monitoring and control, it can be concluded that the security helps by the police officers was given to execute fiduciary execution with high value, huge impact, and wide potential of fights.

Practically, the financial institution has never obtained a fiduciary object with high value; thereby, the execution needs help from police officers. The things received as the object of a fiduciary by the financial institution were mostly vehicles, whether in the forms of car or motorcycle. If the debtor breaches the contract, the institution will do the initial execution. The debt collector will control the initial execution.

In the initial execution, there should be proof of the original fiduciary certificate. In the case of a debt collector, the collector should show the certificate and power of attorney to take the object. Since, according to the Act of Fiduciary, the certificate of fiduciary has executorial power as becoming the verdict of the court which has been in Kracht van gewijsde. A power of attorney is the legal foundation of a debt collector to conduct the action under the order of the creditor (Article 30, Act of Fiduciary and its explanation). Based on those certificates, the debt collector can take the object (conduct initial execution).

\section{Conclusion}

1. The roles of police officers in the execution of the Regulation of Chief of the Indonesian National Police regarding Fiduciary Execution is not the same as Civil Law Execution. According to the Civil Law Execution, police officers are obliged to make the execution success.

2. The types of execution of judge's help, separate executive, and sales execution in the market needed police security, while execution of underhand sales and stock exchange trading execution does not need the help of police security.

3. The absence of security request to fiduciary execution in Regional Police of Central Java and City Police of Semarang is due to:

a. The execution of underhand sales and stock exchange trading execution does not need the help of police security, and the Regulation of Chief of the Indonesian National Police regarding Fiduciary Execution burdens the applicant of police security which is not obliged in Civil Codes;

b. Based on the Regulation of Chief of the Indonesian National Police regarding Fiduciary Execution, the security action will be given to the massive scale of execution which has the possibility of fights to the executor officers and society. In its value, the vehicle is considered relatively small, and the execution scale is considered narrow, making the assistance of the police officers is not needed.

\section{References}

[1] Supomo, Hukum Acara Perdata Pengadilan Negeri. Jakarta: Pradnya Paramita, 1972.

[2] P. W, Hukum Acara perdata di Indonesia. Bandung: Sumur Bandung, 1975.

[3] S. M. S. Mertokusumo., Hukum Acara Perdata Indonesia. Yogyakarta: Universitas Atma Jaya, 2010.

[4] Subekti, Hukum Acara Perdata. Jakarta: Bina Cipta, 1989.

[5] R. ; I. O. Sutantio, Hukum Acara Perdata Dalam Teori dan Praktik. Bandung: Mandar Maju, 1989.

[6] "Institutionalization of the Indonesian Civil Execution Law (TICEL)," J Law, Policy 
Glob., vol. 38, p. 198, 2015.

[7] M. Termorshuizen, Kamus Hukum Belanda Indonesia. Jakarta: Jambatan, 1999.

[8] N. E. . [et. al. Algra, Kamus Istilah Hukum Fockema Andreae, Belanda-Indonesia. Jakarta: Binacipta, 1983.

[9] M. D. Koosmargono, Membaca dan mengerti HIR. Semarang: Universitas Diponegoro, 2012.

[10] C. Sandbrook, The Role of the Police in the Civil Enforcement Process for the Recovery of Land in England and Wales. 2016. 